\title{
Changes in Some Pharmacokinetics Parameters of Chloroquine by Gnetum Africana
}

\author{
Olorunfemi Eseyin ${ }^{1}$, Aniekan Ebong $^{1}$, Anefiok Ubobre $^{1}$, Johnson Ekarika $^{1}$, Imo Udo $^{2}$ \\ ${ }^{1}$ Department of Pharmaceutical and Medicinal Chemistry, Faculty of Pharmacy, University of Uyo, P.O. Box 4274, Uyo, Akwa Ibom, Nigeria; \\ ${ }^{2}$ Department of Biopharmacy and Clinical Pharmacy, Faculty of Pharmacy, University of Uyo, P.O. Box 4274, Uyo, Akwa Ibom, Nigeria
}

Citation: Eseyin O, Ebong A, Ubobre A, Ekarika
J, Udo I. Changes in Some Pharmacokinetics
Parameters of Chloroquine by Gnetum Africana.
Maced J Med Sci. 2012 Oct 15; 5(3):275-279.
http://dx.doi.org/10.3889/M J M S.1957-
5773.2012 .0220$.
Key words: Chloroquine; Gnetum africana;
pharmacokinetics; proximate analysis;
phytochemical screening.
Correspondence:Dr. OLORUNFEMIABRAHAM
Eseyin. Department of Pharmaceutical and
Medicinal Chemistry, Faculty of Pharmacy,
University of Uyo, P.O. Box 4274, Uyo 520003,
Akwa Ibom State, Nigeria. Phone:
+2348065161478.
E-Mail: femieseyin2@yahoo.co.uk
Received: 07-Aug-2011; Revised: 04-Feb-2012;
Accepted:04-Feb-2012; Online first:29-Aug-2012
Copyright: @ 2012 Eseyin O. This is an open
access article distributed under the terms of the
Creative Commons Attribution License, which
permits unrestricted use, distribution, and
reproduction in any medium, provided the original
author and source are credited.
Competing Interests: The author have declared
that no competing intersts exist. that no competing interests exist.

\begin{abstract}
Effect of Gnetum africana on the pharmacokinetic parameters of chloroquine was investigated. Chloroquine phosphate $(200 \mathrm{mg} / \mathrm{Kg})$ was concurrently administered to overnight fasted albino rats. Blood samples were collected 15, 30,60,120, 240 and 480 minutes after administration through cardiac puncture. Serum concentration of chloroquine was evaluated spectrophotometrically. The results indicated that the extract significantly decreased Cmax (9.17\%), Ka (3.06\%), Ke (45.38\%), C, (48.46\%) and $A \cup C\left(_{0-8}\right)(16.90 \%)$. The extract also increased the values of $\mathrm{t}_{1 / 2}(83.11 \%), \mathrm{t}_{\max }(100.00 \%)$. The LD50 of the extract was $5.25 \mathrm{~g} / \mathrm{Kg}$. Phytochemical screening revealed the presence of steroids, tannins, flavonoids and traces of phlobatanins and alkaloids. Proximate and elemental analyses showed that the plant contained Sodium $(26.37+0.01 \mathrm{ppm})$, Potassium $(32.84+0.02 \mathrm{ppm})$, Copper $(0.01+0.00 \mathrm{ppm})$, Calcium (6.53+0.01ppm), Magnesium (7.58+0.02 ppm), Iron (2.01+0.02 ppm), Zinc $(0.93+0.03 \mathrm{ppm})$, Lead $(0.02+0.01 \mathrm{ppm})$, Moisture $(10.90+0.91 \mathrm{mg} / 100 \mathrm{~g})$, Crude protein $(15.31+1.12 \mathrm{mg} / 100 \mathrm{~g})$, Crude fibre $(4.20+0.21 \mathrm{mg} / 100 \mathrm{~g})$, Crude fat $(10.60+0.65 \mathrm{mg} / 100 \mathrm{~g})$, Ash $(5.40+0.30 \mathrm{mg} / 100 \mathrm{~g})$, Carbohydrate $(74.49+0.23 \mathrm{mg} / 100 \mathrm{~g})$ and Energy $(407.80 \mathrm{Kcal})$. The results of this work showed that concurrent administration of the extract of Gnetum africana affected some of the pharmacokinetic parameters of chloroquine. Malaria patients on chloroquine therapy should therefore be advised to beware of consuming Gnetum africana.
\end{abstract}

\section{Introduction}

The primary means of treating protozoan infections is chemotherapy. Unfortunately, the ability of the pathogens to mutate and become drug resistant poses a serious challenge to chemotherapy [1] . Although the mechanism of chloroquine resistance is largely unknown and remains controversial [2] many factors contribute to chloroquine concentration at the target site, which is a major cause of its resistance by the parasite.
Some foods are known to affect the way in which the body handles drugs and therefore have the potentials to either increase or decrease a drug's therapeutic or adverse effects [3]. Some plant materials have been reported to alter some pharmacokinetic parameters of the chloroquine by interfering with absorption, distribution or elimination of the drug. For example, Grapefruit juice is noted for its ability to increase Cmax and AUC [4]; Spinach is capable of maintaining high blood level of chloroquine [5]; Bitter leaf is noted for its ability to 
decrease AUC and therapeutic effect of chloroquine [6]. Azadirachta indica is reported to significantly reduce serum concentration and prolong $\mathrm{t}^{1 / 2}$ of chloroquine [7].

Vegetables are commonly eaten in Nigeria. Incidentally, some of these vegetables have the potentials of interfering with drug absorption and its bioavailability [8]. For example, Telfairia occidentalis and Vernonia amygdalina affect the pharmacokinetics of chloroquine $[9,10]$. The leaves and seeds of Gnetum africana are used for the traditional treatment of enlarged spleen, throat and reduction of pains at childbirth [11]. The seeds are used as antidote for some form of poison and snake bite, and as fungicide for dressing septic or fresh wound $[12,13]$. It is popularly used in salad and soup preparation [11].

This study was carried out to evaluate the effects of concurrent oral administration of Gnetum africana on the pharmacokinetics of chloroquine.

\section{Material and Methods}

Plant Collection: Gnetum africana leaves were collected in 2007 from Uyo, Akwa Ibom State, Nigeria and was identified by Dr Kola Ajibesin of Department of Pharmacognosy and Natural Medicine, Faculty of Pharmacy, University of Uyo, Nigeria.

Extraction: The fresh leaves were oven dried in a Gallenkamp oven for 48 hours at $40^{\circ} \mathrm{C} .5 .0 \mathrm{~kg}$ of the dry leaves were macerated in $15 \mathrm{~L}$ of $96 \%$ ethanol for six days at room temperature. The extract obtained was filtered and concentrated in a Rotary evaporator. The residue was dried in a desiccator containing Silica gel.

Animals: Albino rats (Wistar strain) with a mean weight of $189 \pm 30.1 \mathrm{~g}$ were obtained from the Animal house of the University of Uyo and were given free access to food and water ad libitum.

Evaluation of acute toxicity: The Up and Down method of Bruce (1985) was used to determine the LD50 of the extract [14].

Administration of Chloroquine and Extract: Sixty animals were starved overnight and later divided into two groups of 30 rats each. Group I received chloroquine (15 mg/kg) and extract (200 mg/kg). Group II served as control and was administered chloroquine only $(15 \mathrm{mg} / \mathrm{kg})$. Both Chloroquine and extract were administered orally.
Blood Collection: Blood samples were collected with syringe through cardiac puncture at 15, 30, 60, 120, 240 and 480 minutes under chloroform anesthesia (5 rats per each time point).

Determination of Serum Chloroquine Concentration and Protein Level: The blood samples were left overnight in the refrigerator for the serum to separate. The supernatant serum was collected with a syringe and chloroquine and protein levels determined using UV-VIS spectrophotometer (Unicam 8625). The chloroquine concentration in the serum was determined by extrapolation from a chloroquine standard curve taken at $344 \mathrm{~nm}$.

Elemental and Proximate Analyses: The proximate composition (moisture, crude protein, fibre, ash, fat and carbohydrate) and mineral contents ( $\mathrm{Na}, \mathrm{K}$, $\mathrm{Cu}, \mathrm{Ca}, \mathrm{Mg}, \mathrm{Fe}, \mathrm{Zn}$ and $\mathrm{Pb}$ ) of the plant were determined using the standard methods as outlined by AOAC, 1990 [15].

Phytochemical Screening: The plant was screened for alkaloids, tannins, flavonoids, steroids, terpenes, phlobatannins and anthraquinones using standard procedures $[16,17]$.

Statistical Analysis: The results were expressed as Mean + SD. Student's t- test was used to evaluate the significance level at $\mathrm{P}<0.05$.

\section{Results}

Concurrent administration of the extract significantly affected the pharmacokinetics parameters of chloroquine. Table 1 shows the concentration of

Table 1: Serum concentration of chloroquine $(1 / \mathrm{g} / \mathrm{ml})$ administered alone and concurrently with Gnetum africana extract.

\begin{tabular}{lcc}
\hline Time (minutes) & Chloroquine alone & $\begin{array}{c}\text { Chloroquine and } \\
\text { Gnetum africana }\end{array}$ \\
15 & $2.60 \pm 0.02$ & $0.80 \pm 0.01^{*}$ \\
30 & $7.00 \pm 0.01$ & $2.60 \pm 0.01^{*}$ \\
60 & $19.50 \pm 0.01$ & $4.50 \pm 0.01^{*}$ \\
120 & $24.00 \pm 0.02$ & $15.00 \pm 0.04^{*}$ \\
240 & $22.00 \pm 0.04$ & $20.50 \pm 0.01^{*}$ \\
480 & $15.50 \pm 0.02$ & $17.80 \pm 0.02^{*}$ \\
\hline Mean +S.D.; $n=5 ;{ }^{*} \mathrm{P}<0.05$ &
\end{tabular}

chloroquine values at different time points. Most of the parameters including Cmax (9.17\%), Vd (5.58\%), AUC ${ }_{(0-8)}(16.90 \%)$ and $\mathrm{Ka}(3.06 \%)$ were moderately decreased relative to the control while severe decrease was 
Table 2: Pharmacokinetic parameters of chloroquine phosphate alone and with ethanolic leaf extract of Gnetum africana.

\begin{tabular}{lrr}
\hline Parameter & Chloroquine alone & $\begin{array}{c}\text { Chloroquine and } \\
\text { Gnetum africana }\end{array}$ \\
$\mathrm{K}_{\mathrm{a}}\left(\mathrm{hr}^{-1}\right)$ & $0.9061 \pm 0.011$ & $0.8784 \pm 0.015^{*}$ \\
$\mathrm{~K}_{\mathrm{el}}\left(\mathrm{hr}^{-1}\right)$ & $0.026 \pm 0.007$ & $0.0142 \pm 0.002^{*}$ \\
$\mathrm{~T}_{1 / 2}(\mathrm{hr})$ & $26.65+1.551$ & $48.80 \pm 1.550^{*}$ \\
$\mathrm{t}_{\max }(\mathrm{hr})$ & $2.00 \pm 0.000$ & $4.00 \pm 0.001^{*}$ \\
$\mathrm{C}_{\max }(\mu \mathrm{g} / \mathrm{ml})$ & $24.00 \pm 0.400$ & $21.80 \pm 0.289^{*}$ \\
$\mathrm{C}_{\mathrm{L}}\left(\mathrm{L} \mathrm{kg}^{-1}\right)$ & $4.56 \pm 0.050$ & $2.35 \pm 0.020^{*}$ \\
$\mathrm{~V}_{\mathrm{d}}\left(\mathrm{L} \mathrm{Kgr}^{-1}\right)$ & $175.32 \pm 2.010$ & $165.53 \pm 2.887^{*}$ \\
$\mathrm{AUC}_{(0-8)}\left(\mu \mathrm{g} \mathrm{hml}^{-1}\right)$ & $150.30 \pm 4.500$ & $124.90 \pm 2.236^{*}$ \\
AUC $_{(0-\infty)}\left(\mu \mathrm{ghrml}^{-1}\right)$ & $734.92 \pm 5.000$ & $1378.42 \pm 4.220^{*}$ \\
\hline
\end{tabular}

Mean + S.D.; $\mathrm{n}=5 ;{ }^{*} \mathrm{P}<0.05$.

observed in $\mathrm{Ke}(45.38 \%)$ and $\mathrm{Cl}(48.46 \%)$. The extract significantly increased $\mathrm{t}_{1 / 2}(83.11), \mathrm{t}_{\max }(100.00 \%)$ and AUC $_{(0-8)}(87.56 \%)$ (Table 2). Phytochemical screening revealed the presence of steroids, tannins, flavonoids and traces of phlobatanins and alkaloids (see Table 3 ). The LD50 of the extract was $5.25 \mathrm{~g} / \mathrm{Kg}$. Table 4 gives the results of the elemental and Proximate composition of Gnetum africana leaves.

Table 3: Phytochemical components of Gnetum africana.

\begin{tabular}{|c|c|c|}
\hline S/No. & Component & Result of Phytochemical test \\
\hline 1 & Saponins & - \\
\hline 2 & Tannins & $\overline{++}$ \\
\hline 3 & Anthraquinones & \\
\hline 4 & Phlobatanins & $\mp$ \\
\hline 5 & Alkaloids & + \\
\hline \multirow[t]{4}{*}{6} & Cardiac glycosides & \\
\hline & -Lieberman test : Steroid & +++ \\
\hline & -Salkowski test & $+\overline{++}$ \\
\hline & -Keller Kiliani test & ++ \\
\hline 7 & Flavonoids & ++ \\
\hline
\end{tabular}

$\overline{+++, \text { Present in high concentration; ++, Present in moderate concentration; +, Present in trace }}$ concentration; -, Not present.

\section{Discussion}

Phytochemicals interact with drug transporters and cause impairement of pharmacological activity [1820]. Some elements, notably $Z n$, may induce intestinal proteins which bind drugs and prevent their transfer from the intestine to the body [21]. Reduction in the AUC ${ }_{(0-8)}$ by the extract of Gnetum africana might have been a consequence of the interaction between the drug and some components of the extract. It was reported by O'Brien and Haddad, 2002 [8] that flavonoids inhibited Cyt P450, thereby prolonging the $t_{1 / 2}$ of chloroquine. The flavonoid content of this extract could therefore contribute to the elongation of $t_{1 / 2}$ of chloroquine. In addition, alkalinization of urine by the extract could also contribute to the increase in $\mathrm{t} 1 / 2$ since about $50 \%$ of chloroquine is excreted in urine, of which about $70 \%$ is unchanged.

Table 4: Elemental and Proximate composition of Gnetum africana leaves.

\begin{tabular}{lc}
\hline Composition & Concentration $(\mathrm{ppm})$ \\
Sodium & $26.37 \pm 0.01(\mathrm{ppm})$ \\
Potassium & $32.84 \pm 0.02(\mathrm{ppm})$ \\
Copper & $0.01 \pm 0.00(\mathrm{ppm})$ \\
Calcium & $6.53 \pm 0.01(\mathrm{ppm})$ \\
Magnesium & $7.58 \pm 0.02(\mathrm{ppm})$ \\
Iron & $2.01 \pm 0.02(\mathrm{ppm})$ \\
Zinc & $0.93 \pm 0.03(\mathrm{ppm})$ \\
Lead & $0.02 \pm 0.01(\mathrm{ppm})$ \\
Moisture & $10.90 \pm 0.91(\mathrm{mg} / 100 \mathrm{~g})$ \\
Crude protein & $15.31 \pm 1.12(\mathrm{mg} / 100 \mathrm{~g})$ \\
Crude fibre & $10.60 \pm 0.65(\mathrm{mg} / 100 \mathrm{~g})$ \\
Crude fat & $5.40 \pm 0.30(\mathrm{mg} / 100 \mathrm{~g})$ \\
Ash & $4.20 \pm 0.21(\mathrm{mg} / 100 \mathrm{~g})$ \\
Carbohydrate & $74.49 \pm 0.23(\mathrm{mg} / 100 \mathrm{~g})$ \\
Energy (Kcal) & 407.80
\end{tabular}

Mean + S.D.; $\mathrm{n}=5$

Excretion of chloroquine in urine is decreased by alkalinization of the urine and green leafy vegetables are among the foods that can alkalinize the urine $[8,22$, 23]. The effect of Gnetum africana on half-life of chloroquine was similar to that of Azadirachta indica [7]. Increased tubular reabsorption caused by the alkalinization of the urine could also be responsible for the decrease in the Ke of chloroquine by the plant extract $[24,25]$. The presence of carbohydrates in ileum can slow down gastric emptying by altering gastrointestinal contraction patterns [3]. Decrease in Cmax of chloroquine could be attributable to the presence of the extract which is rich in carbohydrates $(74.49 \%)$ in the gastrointestinal tract.

Gnetum africana have in common with Bitter

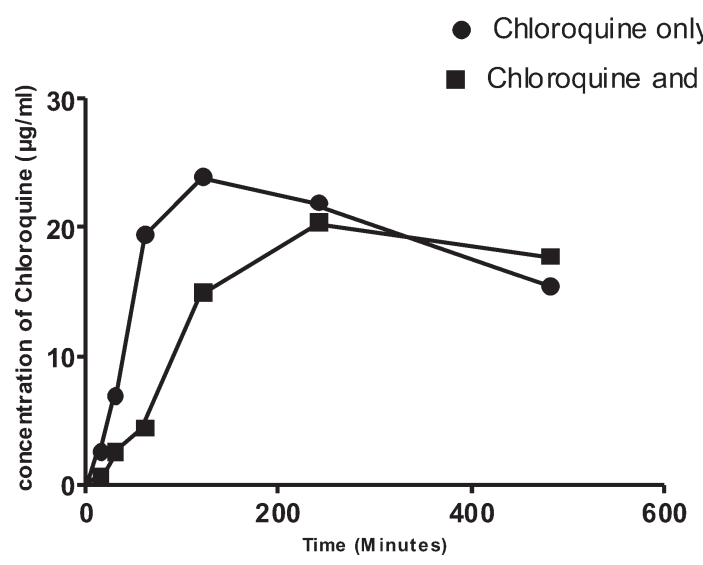

Figure 1: Concentration versus time curve. 
leaf the ability to decrease $C_{\max }$ [6]. Chloroquine has a $\mathrm{t}_{\max }$ range of of between 1.5 hours and 3.0 hours [26] and there is always a change in the height and duration of plasma drug peak whenever a drug is taken orally with food [27]. Food rich in fat and dietary fibre delay the entry of an orally administered drug into the duodenum, delaying absorption and increasing tmax [3]. This may account for the increase in tmax and $\mathrm{Ka}$ of chloroquine by Gnetum Africana. The high LD50 value of $5.25 \mathrm{~g} / \mathrm{Kg}$ shows that the extract is safe for consumption. Okafor et al., 1996 revealed that Gnetum africana leaves contained $37.39,4.72,14.20$ and $10.18 \%$ moisture, ash, crude fat and crude protein, respectively [28]. Results of proximate analysis of the plant agree with the above in the content of ash and crude protein. Similarly, results of elemental analysis of the plants agree in only in the content of Sodium with the report of Okafor et al., 1996 [28].

In conclusion, the results of this work revealed that concurrent administration of the extract of Gnetum africana affected some of the pharmacokinetic parameters of chloroquine. Malaria patients on chloroquine therapy should therefore be advised to beware of consuming Gnetum africana with chloroquine decreased Cmax and AUC of chloroquine by the plant extract may lead to reduced therapeutic effect of the drug and resistance.

However, further work needs to be done using human subjects to ascertain the correlation between the result of this study which was obtained in rat with that of human beings.

\section{References}

1. Wiser M. Mechanism of drug action and resistance (focus on antimalarials). Tulane University, 2003.

2. Sanchez CP, McLean JE, Rohrbach P, Fidock DA, Stein WD, Lanzer M. Evidence for a pfcrt-associated chloroquine efflux system in the human malaria parasite Plasmodium falciparum. Biochemistry. 2005;44 (29): 9862-9870.

3. Mason P. Drug-food interactions (1) food and Medicines. Continuing professional development. The Pharmaceutical Journal. 2002;269:571-573.

4. Ali, BH, Al-Qarawi, A. and Mousa, HM. Effect of grapefruit juice on plasma chlorquine kinetics in mice. Clinical and Experimental Pharmacology and Physiology; 2002;29 (8): 704706.

5. Owoyale JA, Aliu YO, Ayodele JT. Influence of dietary spinach (Amarathion Linn.) on chloroquine blood level in the rabbit. Oriental Journal of Medicine. 1995;7:12-13.
6. Oguntola S. Why bitterleaf may affect your health negatively. Nigerian. Tribune, Friday 28th July, 2006.

7. Nwafor SV, Akah PA, Okoli CO, Onyirioham AC, Nworu CS. Interaction between chloroquine sulphate and aqueous extract of Azadirachta indica A Juss (Meliaceae) in rabbits. Acta Pharmaceutica. 2003;53(4):305-11.

8. O'Brien D, Haddad AR. Consulting patients on drug-food interactions. U. S. Pharmacist. 2002;22(6).

9. Eseyin OA, Edoho EJ, Igboasoiyi AC, Nwadiukwu E, Ekpo A. Effects of the leaf extract of Telfairia occidentalis on the pharmacokinetic of chloroquine. International Journal of Biological Chemistry. 2007;1(4):256-260.

10. Igboasoiyi AC, Eseyin OA, Udoma NF. The effect of ethanolic extract of Vernonia amygdalina leaves on some pharmacokinetic parameters of chloroquine in rats. Research Journal of Pharmacology. 2008;2(2):24-27.

11. Etukudo I. Ethno botany: conventional and Traditional uses of plants. The Verdit press, Uyo, 2003.

12. Itah AY. Screening of plants for fungal properties. Trans Nig Soc Bio Conserv. 1996;4(1):26-40.

13. Ekop AS. Determination of chemical composition of Gnetum africana seeds. Pak J Nutrition. 2007;6(1): 40-43.

14. Caprette DR. Preparation and use of standard curves. Rice University,2000.

15. AOAC. Official methods of Analysis. 15th ed. Association of Official Analytical Chemists, Arlington, 1990.

16. Harbone JB. Phytochemical methods. London, Chapman and Hill, 1973.

17. Sofowora ER. Guidelines for research promotion and development in traditional medicine. Nigeria Journal of Pharmacy. 1980;11:117-118.

18. Guengerich FP. Role of cytochrome P450 enzyme in drugdrug interaction. Advance Pharmacol. 1997;43:7-35.

19. Lin JH, Lu AYA. Inhibition and induction of cytochrome P450 and the clinical implications. Clinical Pharmacokinetics. 1998;35:361-390.

20. Ioannides C. Drug - phytochemical interactions. Inflammopharmacology. 2003;11(1):7-42.

21. Schrauzer GN. "The discovery of essential trace elements: An outline of the history of biological trace elements research". In: biochemistry of essential trace elements, edited by Earl Frieden. Plenum, New York, 1984:17-31.

22. Mechesney EW, Fasco MJ, Banks WF. The metabolism of $\mathrm{CQ}$ in man during and after repeated oral dosage. Journal of Pharmacy and Experimental Therapeutics. 1967;158:323-331.

23. Gustafsson LL, Walker O, Alvan G, Beermann B, Estevez 
F, Gleisner L, Sjoqvist F. Disposition of chloroquine in man after single intravenous and oral doses. British J Clinical Pharmacol. 1983;15:471-479.

24. Rowhand M, Tozer TW. Clinical pharmacokinetics-concepts and applications. 3ed. Lippincott Williams and Wilking, 1995.

25. Wallace AW, Amsden GW. Is it really Ok to take this with food? Old interactions with new twist. The Journal of Pharmacology. 2002;42:437-443.

26. Jaeger A, Flesch F. Chloroquine. IPCS, 1994. Available online at http://www.inchem.org/documents/pims/pharm/ chloroqu.htm

27. Bonate PL, Howard DR. Pharmacokinetics in drug development: clinical design and analysis (1). American association of pharmaceutical scientists, Arlington, VA, 2004: 235-278.

28. Okafor JC, Omoradion F, Amaja FI. Non-timber forest products (Nigeria): Consultancy paper prepared by the Evaluation and Co-ordination Unit (FORMECU) and Federal Department of Forestry (FDP) Abuja, Nigeria, 1994:8. 